\title{
A Translation Study on School Signboards in Surakarta: Types, Functions, And Quality
}

\author{
Ardianna Nuraeni, Fenty Kusumastuti, M.R. Nababan \\ Sebelas Maret University, Surakarta \\ Email: anna_aeni@yahoo.com.sg
}

\begin{abstract}
This research aims to map out types of bilingual signboards found in Elementary and Secondary schools in Surakarta based on their functions, to assess their quality in terms of accuracy and acceptability, and to describe factors influencing the translation quality. This descriptive qualitative research used data sources in the form of documents and persons, i.e. bilingual signboards displayed on school walls and those called raters who have competencies in assessing translation quality. Content analysis, Interview, and Focus Group Discussion were applied as the methods to collect and analyze the data of bilingual signboards. As a result, there are three types of school signboard, namely signboards showing names of place, signboards showing the condition of a particular place, and those saying proverbs. Dealing with the function, signboards having informative, suggestive, restrictive and mandatory functions are identified. The majority of the data resulting accurate and less acceptable translation is found in universal signboards, while culture-bound signboards tend to be rendered less accurate and less acceptable due to some factors that can be read thoroughly in this article.
\end{abstract}

Keywords: translation, school signboards translation, translation accuracy, translation acceptability

\section{INTRODUCTION}

The existence of International Standard Schools (or Sekolah Bertaraf Internasional or SBI in Indonesian term) had once been popular before it was finally reviewed by Constitutional Court in 2013 and changed into Top Schools (Sekolah Unggulan). The Act Number 20 of 2003 on National Education System, particularly Article 50, Verse (3) states that government and local governments organize at least a unit of education [one school] at all levels of education, to be developed as a unit having international standards of education, and this act is the framework of SBI's development. The Article is supported by Permendiknas 70 of year 2009 on the Development of International Standard School at Elementary and Secondary
Education. This rule is a clear evidence that it is the governments' effort to create an exceptional school, related to Article 2 of Permendiknas as the objective of creating SBI. One of the purpopes is to produce competent graduates who are able to communicate in foreign language. This led us to the fact that the increasing demand of teachers who are able to teach in English and all things in school created bilingual platform - Indonesian and English - including school signboards that are hung on school walls. This phenomenon is also occured in SBI of Surakarta. Unfortunately, this honorable intention was practiced carelessly that there is an assumption that the school is not ready and serious in creating international atmosphere. The worse 
thing is that the phenomenon does not occur only in SBI but is also followed by non-SBI schools, exposing bilingual signboards in every corner of the school.

Bilingual Signboards should support the improvement of students reputation, especially in English, to show that they are ready to compete in international level. Besides that, the existence of bilingual signboards also show the cool image in carrying the portray of their international label. While for the non SBI schools these bilingual signboards serve as a tool to raise their prestige and to build trust among the society that the schools do not have less abilities compared to SBI schools, for the purpose that these schools can draw new more students. The fact is that the signboard translations displayed on school corners tend to be written by ignoring English conventions. Principles of modesty and propriety values that are often written and/or implied on signboards in Indonesian culture is different to those in western culture. The persons responsible for the translation of bilingual signboards in their schools need to pay special attention to these principles instead of relying on translation machine.

Several researches with the topic public signs were conducted in the context of translating Chinese to English, and one of them is a study on translating public signs in China as seen in Skopos Theory Approach by Hua (2007), classification of public signs based on their functions and their linguistic features (Kang \& Zhang, 2008), the application of communicative translation approach in translating public signs from Chinese to English (Jing-Jing, 2011), and a research on mistakes/errors in translating public sings from Chinese to English by Guo (2012). Similar study is very rarely found in Indonesia, which proves the fact that theory and discussion of public sign translation is rare. Therefore, for this reason the researcher considers it as an opportunity to conduct this research even in a small scale, such as elementary and secondary school in Surakarta.

School signboards can be categorized as a public sign, which is a sign that is displayed in public area, has an important role and that is to give information and instructions (Hua, 2007: 2). Kang \& Zhang (2008) define public signs as words or drawings that are placed in public place and are used to give information, suggestion, and to warn people. According to Lü He-fa (2005) (in Jing-Jing, 2011: 14), public signs have four main functions that are contradictory to each other : (1) Information Function, signs conveying information only and not asking people to do something, such as Waiting Room, ATM and Library Room; (2) Suggestive/Reminder Function, signs to suggest/ remind people about what they have to do in related with specific signs, such as Be Careful, Caution! Wet Floor, and Maximum Height; (3) Restriction Function that restricts people from doing something without making them feel dictated, such as Only Staffs are Allowed to Enter, Two-Wheels Only, and Right Lane for Cars; and also (4) Coercive/Imposing Function that requires people to act and obey the present regulation, such as No Enter, No Smoking and Guns are Prohibited.

To translate public signs into English, an understanding of linguistic features of public signs is required to enable the researcher in analyzing school sign board translation, giving suggestions in revising the translation, and also giving standards in making excellent quality of school signboards. In his/her article, Guo (2012) states that the basic characteristic of public signs in general must consider a correct grammar and spelling, with a short and clear language, a precise word choice, commonly used words, comprehend the cultural differences. Agreed to Guo, Kang \& Zhang (2008: 125) also state that public signs should use simple words or everyday language with short vocabularies, clear and brief. They argue that this is in accordance with the purpose of making public signs, that is to make people understand the message in a short time. It means that using unusual words, slang, or technical terms should be avoided. Understanding of linguistic features of public signs is required to enable the researcher in analyzing school signboard translation. Kang \& Zhang (2008, 126-127) state that some translation principles are usually applied in translation of public sign expressions. The principles state that public signs should: (1) be easy to understand; (2) be definite in meaning; (3) be brief ; (4) be proper in tone (precise and polite); and (5) use standardized words and avoid translating word-for-word;

Translation Quality Assessment determines whether the purpose of translation of signboards in 
schools in Surakarta has been achieved or not. In measuring the quality of translation, the researcher applied two instruments, they are accuracy and acceptability. As a part of translation quality assessment, the acceptability factor of a text should be in line with the grammatical equivalence of target language and the readers' attitude towards the target language text (Nababan, 2010). As part of the culture, language is regarded as acceptable if the language considers the language elements and accomplish a natural expression.

This study aims at (1) mapping different kinds of signboards according to their functions; (2) assessing the translation quality of these signboards; and (3) identifying factors that determine translation quality. The outcome of the result is expected to open the eye and raise awareness in society that translating texts is not as easy as they imagine. Translation on signboards require special attention as wrong translation will lead to confusion among the students. Moreover, this study will also reveal the condition of signboards translation in schools that in the future, the standard of bilingual signboards formula can be constructed.

This is a qualitative descriptive research with documents as the data sources, that is bilingual signboards displayed in elementary and secondary schools in Surakarta. The objectives of the research are to describe data on the signboars translation and to describe the factors that influence the quality of the translation. The content analysis method was to map the types of signboards according to the functions and also to assess the translation quality. In the beginning of the study, the researcher collected the data by conducting surveys - visited schools in Surakarta. After that, documentation of the data was conducted by taking pictures of signboards with the permission of respected school heads. Interviews with the school representatives were conducted to know the process of making signboards. The researcher then conducted interviews with some teachers and students of the schools. Another method in collecting data was conducting Focus Group Discussion (FGD) with raters by using questionnaire as a tool in collecting the data. The data on translation quality that covers accuracy and acceptability aspects were obtained in the form of scores and direct arguments from the raters. Furthermore, the alternative translation that is more accurate and acceptable was also obtained from the FGD session.

\section{DISCUSSION}

From some schools of elementary and high schools in Surakarta, which have and display bilingual signboards, there are totally 119 data of Indonesian-English signboards. From the data, the study shows that there are 4 types of signboards categorized based on their function, i.e. those having informative/indicative functions (88 data), suggestive function (29 data), restrictive function (1 datum), and mandatory function (1 datum). From that distribution, it is obvious that the majority of signboards in schools are functioned to give information to the readers. This condition proves that people tend to give attention to informative matters due to a fact that this kind of function is felt more comfortable for them since it merely does not command them directly to do something. Two types of signboards having this informative function are found in signboards showing names of place (such as Ruang UKS Medical Treatment Room, Perpustakaan-Library, Laboratorium Bahasa - Language Laboratory) and those showing the condition of a particular place (Tutup - Closed).

The second major number of signboards falls in the category of suggestive function. This finding gives a fact that people also need to be reminded of things (that) should not be done and most of these data are in the form of proverbs. Proverbs were born from general wisdom of a society so its meaning is highly influenced by cultural concepts of the people. Proverbs can be identified into two groups, i.e. universal proverbs and culture-bound proverbs. Pengalaman adalah guru yang terbaik (Experience is the best teacher) is an example of universal proverb, while Rajin Pangkal Pandai, Hemat Pangkat Kaya (Diligent is the basic of cleverness, thrifty s the basic of wealth) is an example of culture-bound proverb, which reflects wisdom of the way Indonesian people applying diligent way of life to achieve success and adjusting their economic condition to invest for their future.

Data of signboards having restrictive function and mandatory function are very rarely found in 
Surakarta's schools. There is only 1 datum in each category of function, for instance, Terima kasih Anda tidak merokok di area ini that is translated into Thank you for not smoking in this area. The language used in this restrictive signboard presents politeness sense in the use of politeness marker Terima kasih/ thank you to make the readers do not feel offended and unacceptable (Hua, 2007). In fact, the signboard is clearly intended for forbidding anyone to smoke in the area. This probably relates to the norm in the society that to show polite manners people should not dictate and push others to obey rules and regulations strictly. An example of signboard with mandatory function can be seen in the datum saying Jagalah Kebersihan, which is translated into No Littering. The directness of the imperative part can be identified from the absence of politeness marker in the English translation and the presence of the word No that does not give a room for any negotiation, of which the readers have no other choices but to follow it (Hua, 2007).

The first analysis to the signboard translation quality discusses the accuracy level of the translation product. As Bell (1991: 11) states, one of general laws of translation is that "translation should give a complete transcript of the ideas of the original work". Accuracy relates to "preservation of the information content of ST in TT" (Shuttleworth \& Cowie, 1997: 3). Dealing with the faithfulness of message transferring, the finding reveals that the English version of the school signboards tends to be accurate since, out of 119 data, there are 81 data are rated as accurate translation, 31 data less accurate and only 7 data inaccurate. Before we discuss further about the accuracy aspect, school signboards can be grouped into two main categories, i.e. signboards showing names of places and signboards in the form of proverbs. Based on these two groups, the tendency of accurate data comes from the first group having informative function, with 68 data. Like proverbs category, signboards showing names of places, also consist of two categories. They are universal signboards and school-bound signboards. And as we have predicted, most of accurate signboards are produced from the universal ones, such as Ruang BK - Guidance and Counseling Room, Penerima Tamu - Receptionist, and Ruang Rapat-Meeting Room. On the contrary, school-bound signboards - signboards showing specific characteristic of given schools - are mostly assessed as less accurate. They are found in STM 2, SMPN 1, and SMAN 3 , as follows.

(a) Ruang Multimedia - Teaching Learning Media Room

(b) KK. Teknik Permesinan - Mechanical Engineering Department

(c) Ruang Elektronika - Electronic Room

(d) Ruang Karawitan - Traditional Music Room

(e) Ruang Kebaktian - Religion Classroom

In (a), the translated signboard is assessed as less accurate by the raters since the meaning of the word multimedia is not equivalent with that of media. Meanwhile, the additional words of teaching learning in the Target Text (TT), usually named as amplification technique (Molina \& Albir, 2002: 510), is considered as a good decision because they do not change the meaning of the Source Text (ST). It makes the meaning more obvious, instead. The translation of signboard in (b) is also less accurate because the translator wrongly translates the name of the discipline Teknik Permesinan. Mechanical Engineering underlines a discipline that studies engineering related to mechanic system, and not related to machine. The lower assessment on accuracy in (c) is caused by the incorrect translation of the word Elektronika. What is meant by Ruang Elektronika in the ST is a room that has a function to study Electronics subject, i.e. a room where students assemble particular electronic devices such as radios, adaptors, etc. Instead of employing such a meaning, the TT Electronic Room has different meaning since the word electronic has no meaning related to an Electronics subject. The cause making (d) less accurate is the non-equivalence of the meaning employed in the word traditional music as the translation of Karawitan. Karawitan refers to a set of music instruments originated from Java. When it is only rendered into traditional music, the Javanese culture flavor has not been achieved yet. To make the translation more accurate, the suggested translation for Ruang Karawitan is probably Karawitan Room, in which Borrowing technique is applied, or Javanese Traditional Music Room, in which Amplification technique is used. Signboard (e) is only found in SMAN 3 Surakarta. 
Ruang Kebaktian in this school is functioned as a praying room for Christian students - like a mosque for Muslims. Its translation Religion Room is also considered less accurate due to its different meaning employed because Religion Room can be assumed to be used by students of any religion to do their religious activities.

Another interesting finding due to variation in translation is also revealed. There are differences of the translated signboards in some schools, especially those showing names of places. The followings are the examples.

(a) ST : Ruang UKS

TT 1 : School Health Service

TT 2 : Medical Treatment Room

TT 3 : Health Center

Picture 1. School Health Center

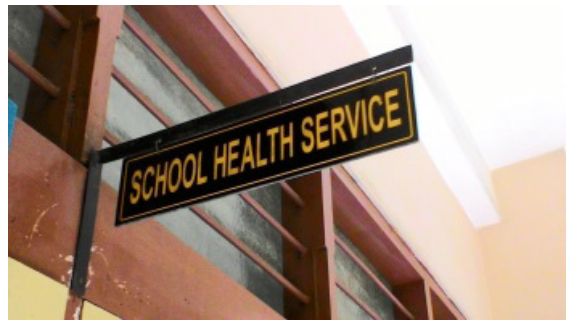

Picture 2. Medical Treatment Room

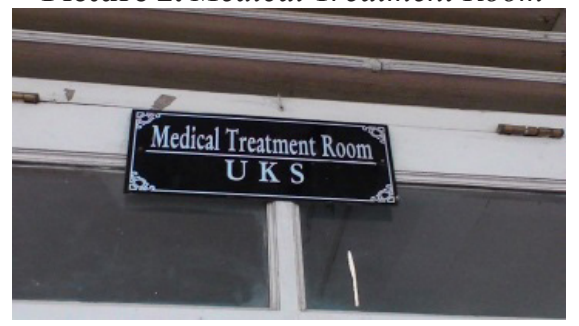

Picture 3. Health Center

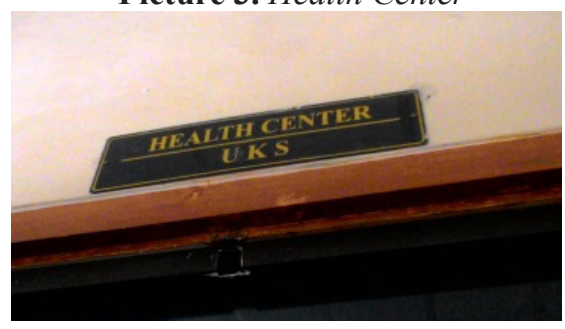

(b) ST : Ruang (Kantor) Kepala Sekolah TT 1 : Headmaster

TT 2 : Principal's Office (2 data)

TT 3 : Headmaster Room
Picture 4. Headmaster Room

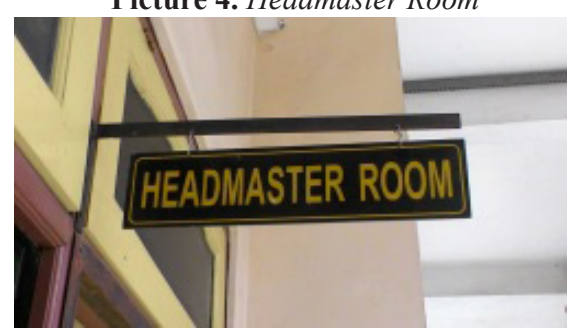

Picture 5. Principal's Office 1

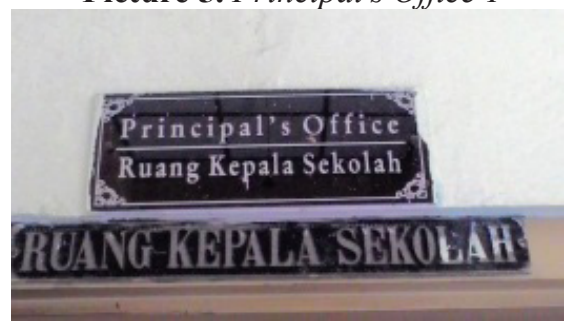

Picture 6. Principal's Office 2

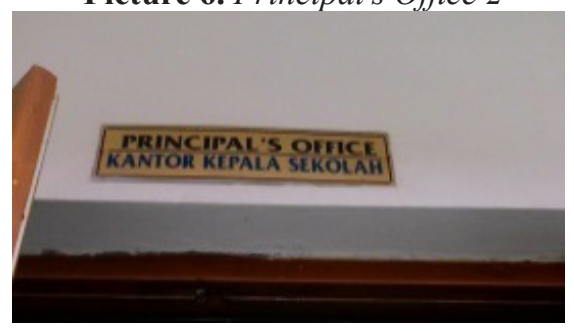

Picture 7. Headmaster

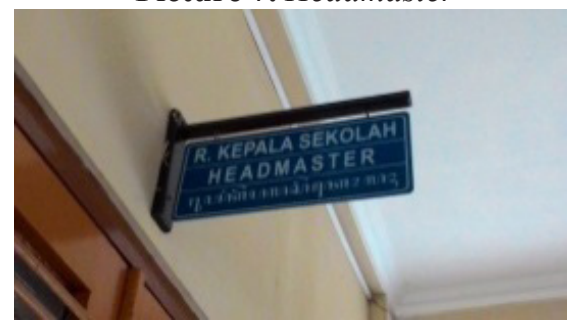

(c) ST:Kantin

TT 1 : Food Court

TT 2 : Canteen

Picture 8. Food Court

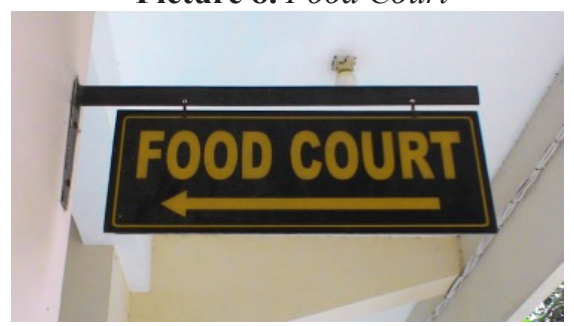




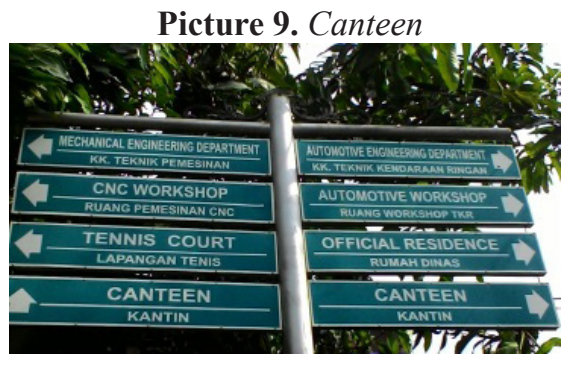

In the example (a), Ruang UKS (Usaha Kesehatan Sekolah) is translated differently by three schools. In other words, every school translated the signboard based on their own interpretation and version. From those versions, TT 1 School Health Service is rated as a less accurate translation since the word service refers to "the ACTIVITY of health service given", and does not refer to the room as intended in the ST. On the other hand, TT 2 and TT 3 have brought the same message as that in the ST. Medical Treatment Room and Health Center are already equivalent with the concept of $U K S$ in schools in Indonesia, i.e. a room or a place functioned to treat students who need health service. TT 2 clearly states the word room, which is considered (by the raters) has given information about a place, while TT 3 does not present the word school in it but it has given a complete meaning to readers from its context of situation. The signboard is displayed at school and the health center operates at school, so the absence of the word school in TT 3 does not reduce the whole meaning of it.

Example (b) shows a difference in the choice of word headmaster and principal as the translation of kepala sekolah. In fact, the two English words have different meaning. Headmaster brings a wider meaning in the TT culture because it covers both the head teacher of a school and the senior teacher in a school. On the contrary, principal employs the exact meaning as it demanded in the word kepala sekolah in Indonesia, i.e. the person in charge of a school for children aged between approximately 11 and 18 . Thus, TT 1 and TT 3 are placed in the category of less accurate translation. According to Kang \& Zhang (2008, 126-127), one of the principals of signboard translation is it has to be simple in order that the readers understand it easily. To fulfill the principal, simple and easy to be understood, for instance, the word room and/ or office in all of the translation versions has to be omitted, so that the signboard will only say Principal.

The last example, example (c), kantin is rendered into food court and canteen. In this case, both translations have employed the same meaning as that in the ST, i.e. a place to buy food and beverages. Moreover, nowadays, food court is very familiar for Indonesian people as the place is commonly found in shopping centers such as malls in Surakarta.

The analysis on the second type of signboards, i.e. signboard in the form of proverbs, shows that those signboards also tend to be translated accurately. From totally 31 data of proverbs, 19 data are assessed accurate, 9 data less accurate and only 3 data inaccurate. See the pie chart below to get a clear distribution of the accuracy of proverb translations.

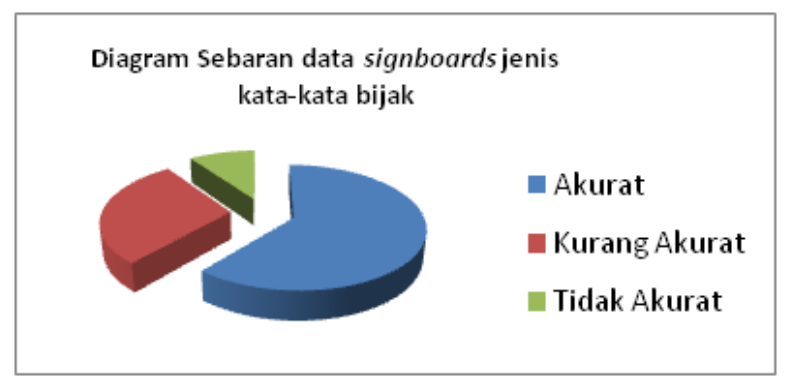

Picture 10. Distribution of accuracy of proverb translations

As mentioned before, these proverbs are grouped into two main categories; they are universal signboards and culture-bound signboards. The following table presents some data of proverbs coming from both categories together with the result of their accuracy assessment. 
Table 1. Example of Signboards in the Form of

Proverbs and Their Accuracy Assessment

\begin{tabular}{|c|c|c|c|}
\hline \multicolumn{2}{|c|}{ Data Category } & \multirow[t]{2}{*}{ Translation } & \multirow[t]{2}{*}{ Accuracy } \\
\hline Universal & Culture-Bound & & \\
\hline Buku adalah sahabat terbaikmu. & -- & A book is your best friend. & Accurate \\
\hline $\begin{array}{l}\text { Pengalaman adalah guru yang } \\
\text { terbaik }\end{array}$ & -- & Experience is the best teacher & Accurate \\
\hline Kami datang untuk belajar & -- & We come to learn & Accurate \\
\hline $\begin{array}{l}\text { Setiap orang akan mendapatkan } \\
\text { hasil sesuai dengan perbuata- } \\
\text { nnya }\end{array}$ & -- & As you sow so shall you reap & Accurate \\
\hline $\begin{array}{l}\text { Semua yang besar dimulai dari } \\
\text { sesuatu yang kecil }\end{array}$ & -- & $\begin{array}{l}\text { Every big thing starts from a } \\
\text { small thing }\end{array}$ & Accurate \\
\hline $\begin{array}{l}\text { Orang yang berotak kosong } \\
\text { biasanya banyak omong dan } \\
\text { membual }\end{array}$ & -- & $\begin{array}{l}\text { Empty vessels make the most } \\
\text { sound }\end{array}$ & Accurate \\
\hline $\begin{array}{l}\text { Ilmu pengetahuan adalah pen- } \\
\text { erang dalam kegelapan }\end{array}$ & -- & $\begin{array}{l}\text { Science as the light from the } \\
\text { darknes }\end{array}$ & Less Accurate \\
\hline $\begin{array}{l}\text { Hari ini harus lebih baik daripa- } \\
\text { da hari kemarin }\end{array}$ & -- & $\begin{array}{l}\text { Today must be better from the } \\
\text { previous }\end{array}$ & Less Accurate \\
\hline \multirow[t]{5}{*}{$\begin{array}{l}\text { Didalam tubuh yang sehat } \\
\text { terdapat jiwa yang kuat }\end{array}$} & -- & $\begin{array}{l}\text { In healt body we can find the } \\
\text { good sout }\end{array}$ & Inaccurate \\
\hline & $\begin{array}{l}\text { Allah menolong orang yang } \\
\text { tekun dan pantang menyerah }\end{array}$ & $\begin{array}{l}\text { Allah helps the diligent and } \\
\text { perseverant people }\end{array}$ & Less Accurate \\
\hline & $\begin{array}{l}\text { Rajin pangkal pandai, hemat } \\
\text { pangkal kaya }\end{array}$ & $\begin{array}{l}\text { Attentive goes to bright, effi- } \\
\text { cient goes to rich }\end{array}$ & Inaccurate \\
\hline & Sopan dalam kelakuan, San- & Polite fr & Inaccurate \\
\hline & & $\begin{array}{l}\text { om the behaviour, honst from } \\
\text { the converse }\end{array}$ & \\
\hline
\end{tabular}

From the table, it can be clearly seen that universal signboards tend to be rendered accurately. This is probably caused by how people from many countries see the world from the same point of view and how they share that same concept about life. Thus, it is naturally believed that Indonesian universal signboards can be transferred into English equivalently. On the other hand, culturebound proverbs are definitely found having lower quality. Because local culture brings its own uniqueness, translating a text is often seen as an activity that is hard to do. An example of culturebound signboard can be found below.

ST : Allah menolong orang yang tekun dan pantang menyerah

TT : Allah helps the diligent and perseverant people

The cultural flavor in the example is presented in the word Allah, a religion-related word that reflects the way Moslems and Christians in Indonesia call their Creator. Instead of using the word God, which is surely more general for any religion believers, the signboard using the word Allah is, probably, intentionally made due to the large number of Moslem and Christian students in Indonesia. That is the reason why the signboard is placed in the category of culture-bound signboard.

The second way to assess translation quality is done by rating acceptability level of the translated signboards. This is in line with Nababan's statement saying that translation quality assessment can also be focused on the naturalness of receptor language/ acceptability (2003: 86). The concept of naturalness was also proposed by Nida (1964). When discussing on equivalence in translation, he says that translation equivalence covers two characteristics, i.e. "equivalent", which refer to the Source Language (SL) message, and "natural", which refer to the receptor language, 
and he also elaborates that "natural" refers to three areas of communication process: a natural rendering should fit the whole receptor language and culture, the context of the specific message, and the receptor language audience (Nida, 1964: 166). While Machali (2000: 115-117) explains that naturalness deals with natural spelling, diction, and expression. From those theories, the assessment of acceptability is focused on cultural aspect, choice of word or diction, and also sentence structure. From 119 data of signboards, it is found 63 acceptable data, 47 less acceptable data, and 9 unacceptable data. The majority of acceptable translated-signboards come from the category of signboards showing names of places such as Administration Room, Teachers' Room, Principal's Office, Science Laboratory, Hall, Food Court, Library, and Language Laboratory and those are the universal ones. In contrast, culturebound signboards such as Ruang Pramuka, Ruang Kebaktian, Ruang Elektronika, Ruang Seni Tari, and Ruang Multimedia are rated less acceptable. Lastly, signboards showing names of places that are assessed as unacceptable data are caused by the absence of the names of the rooms in the TT culture, such as Ruang Pengembangan and Ruang Apresiasi found in SMPN 1 Surakarta. Compared to the data distribution in terms of accuracy, the composition of acceptable data is slightly lower in number. See the diagram below about the comparison of data distribution between accuracy aspect and acceptability aspect.

Picture 11. Number of Data Comparison between Accuracy and Acceptability Aspect

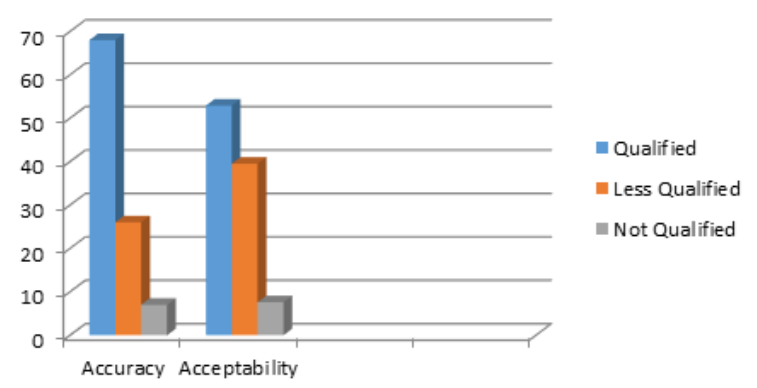

The analysis towards accuracy and acceptability is not completely done without analyzing some factors influencing it. The factors making the translated-signboards less qualified can be summarized in the following table.
Table 2. Factors Influencing the Translation Accuracy and Acceptability

\begin{tabular}{|c|c|}
\hline $\begin{array}{l}\text { Translation } \\
\text { Quality }\end{array}$ & $\begin{array}{l}\text { Factors Influencing the Translation } \\
\text { Quality }\end{array}$ \\
\hline Less Accurate & $\begin{array}{l}\text { a. Mistranslating names of discipline/ } \\
\text { school subject } \\
\text { b. The use of wrong dictions having } \\
\text { similar meaning such as science } \\
\text { and knowledge } \\
\text { c. The use of wrong word class } \\
\text { causing different meaning (noun } \\
\text { translated into adjective) } \\
\text { d. Literal translation and/or word-for- } \\
\text { word translation } \\
\text { e. Wrong tenses } \\
\text { f. Mistranslating the function of a } \\
\text { room } \\
\text { g. Wrong sentence structure creating } \\
\text { meaning distortion }\end{array}$ \\
\hline Inaccurate & $\begin{array}{l}\text { a. Wrong sentence structure causing } \\
\text { unclear meaning } \\
\text { b. Word-for-word translation } \\
\text { c. Misinterpreting and translating the } \\
\text { function of a room }\end{array}$ \\
\hline Less Acceptable & $\begin{array}{l}\text { a. Wrong grammar (single-plural) } \\
\text { b. The use of unnecessary } \\
\text { punctuation } \\
\text { c. Wrong sentence structure (double } \\
\text { verbs such as "get think" and no } \\
\text { verb) } \\
\text { d. Wrong dictions having similar } \\
\text { meaning such as way and road, } \\
\text { sound and noise } \\
\text { e. Wrong tenses } \\
\text { f. The use of wrong word class } \\
\text { g. Wrousing different meaning } \\
\text { g. Wrong spelling }\end{array}$ \\
\hline Unacceptable & $\begin{array}{l}\text { a. Unnatural translation of names of } \\
\text { room in the TT culture }\end{array}$ \\
\hline
\end{tabular}

As the factors influencing the quality of the translated-signboards identified, problems in producing English school signboards in Surakarta can then be deduced. Most of the problems come from linguistic matters, such as problems in grammar, problems in choosing correct diction, problems in tenses, problems in spelling, and also problems in producing good English sentence structure.

a. Problems in grammar

Example: Membaca dapat membuka pintu dunia

Reading can be opening the world gate 
Ilmu pengetahuan adalah penerang dalam kegelapan

Science as the light from the darknes

As we can see in the examples, the problem of wrong grammar gives a consequence to a weird meaning of the translation produced. The first shows us how the odd grammar can be opening difficult to understand, since it brings no clear logical meaning in English. The second example saying Science as the light from the darknes has no verb in it. According to Taylor (in Dabaghi, Pishbin \& Niknasab, 2010: 807), a characteristic of proverbs is they are grammatical sentences. He explained that proverbs must be complete sentences. Thus, the problem of incomplete sentence in the second example should be revised into Knowledge is a light in the darkness, for instance. In addition, there are two other mistakes making this proverb less readable, they are: (1) the phrase the light from the darknes with an emphasis on the preposition from that should be replaced by of; and (2) the spelling of the word darknes.

b. Problems in choosing correct diction

Example: Kami datang untuk belajar, Kami pulang membawa ilmu

We come to learn and we bring back $\underline{\text { science }}$

Orang yang berotak kosong biasanya banyak omong dan membual

Empty vessels make the most sound

Percaya diri adalah jalan menuju sukses

Self confidence is way to succest

The three examples above obviously show the problem of the translator in choosing words having similar meaning. Such words are what Baker referred to as near-synonyms (1992:13). The word science should be replaced by knowledge to produce a proverb We come to learn and we bring back knowledge. In the second example, the word sound is also not correctly used in the proverb. The translator seem not realizing that the proverb has been established in English culture as Empty vessels make the most noise. Similar to the two previous examples, the third proverb Self confidence is way to succest presents a wrong diction, by putting aside a case of wrong spelling succest, of which the translator cannot differentiate the use of way and road. By considering a proverb Books are road to success, $\mathrm{s} /$ he should translate Percaya diri adalah jalan menuju sukses into Self-confidence is a road to success.

c. Problems in tenses

Example: Ketekunan temukan kebahagiaan Attractivenes found the happiness

A case of wrong tenses can only be found in the example above. "Proverbs are wisdoms of true words" (Meider 1985: 119 in Dabaghi, Pishbin \& Niknasab, 2010: 807), and that is the reason of why proverbs are presented in Present Tenses. By ignoring the wrong dictions used by the translator, the word found must be replaced by find. Overall the proverb Ketekunan temukan kebahagiaan should be translated into Perseverence is the mother of happiness.

d. Problems in spelling

Example: Kesuksesan datang dari iman yang kuat

Succesful comes from the strength faith

Percaya diri adalah jalan menuju sukses

Self confidence is way to succest

Problem in spelling is mostly found in the signboard translation produced by the translator of SDN 83 Surakarta. From the underlined words in the two examples, it can be clearly seen that the words should be rewritten into SUCCESSFUL and SUCCESS.

Based on this fact, it seems that the translators of those signboards still do not possess the Linguistic Competence well. Referring to Kang $\&$ Zhang's theory (2008) on the principals of making good signboards, the English signboards displayed in Surakarta's schools have not fulfilled the principals, especially in the aspect of "be brief" 
and "the use of standardized words". Moreover, there are still many numbers of signboards in the form of proverbs that are translated using wordfor-word translation technique and this strengthens our conclusion stating that the translators do not have a good competency of language. Moreover, the fact that there are some variations of signboard translation of the same Indonesian signboard proves that there are no standardized guidelines of how to produce good English signboards yet.

\section{CONCLUSION}

Based on the findings of this study, it can be concluded that the majority of signboards at school in Surakarta are in the form of those showing names of room and having informative function, while signboards in the form of proverbs are rarely displayed at the schools area. From the two types of school signboards, the first type gives a high level of accuracy, which means that the translators do not have any problems in rendering such signboards. This is probably due to the universal characteristic of the signboards and, probably, the availability of abundance parallel texts easily found in the internet. On the other hand, the second type of school signboards is translated by ignoring the signboard translation principals since a large numbers of proverbs are still transferred using literal translation and wordfor-word translation technique resulting low level of acceptability. Schools belonging to qualified ones in Surakarta, such as SMPN 1, SMPN 4, SMAN 3, STM 1, and Kleco Elementary School tend to display better translated-signboards, both from the accuracy and acceptability aspect. But, in general, schools in Surakarta observed in this study still need to improve the quality of their signboard translation to meet the principals of public signs translation. This is merely to achieve the core purpose of why bilingual signboards should be displayed at schools. Thus, we do expect that our next study on school signboards can be done within a wider scope in order to propose a prototype of standardized school signboards that can be used as a guideline for parties who want to produce their school signboards.

\section{REFERENCES}

Baker, M. (1992). In Other Words. London: Routledge.

Bell, R.G. (1991). Translation and Translating: Theory and Practice. London \& New York: Longman.

Dabaghi, Pishbin \& Niknasab. (2010). Proverbs from the Viewpoint of Translation. In Language Teaching \& Research Journal, Vol. 1, No. 6, p. 807-814. ISSN 1798-4769. Retrieved on $27^{\text {th }}$ October, 2011, from http://ojs. academypublisher.com/index.php/jltr/article/ view/0106807814/2276

Guo, M. (2012). Analysis on the English-translation Errors of Public Signs. In Theory and Practice in Language Studies, Vol. 2, No. 6, p. 1214-1219. ISSN 1799-2591. Retrieved on $25^{\text {th }}$ March, 2015, from http://www.academypublication. com/issues/past/tpls/vol02/06/17.pdf

Hua, H. (June, 2007). On the C-E Translation of Public Signs from the Perspective of Skopos Theory. Xiaogan University.

Jing-Jing, W. (2011). A Communicative Translation Approach to Chinese-English Translation of Public Signs. Dalam Jurnal Social and Cultural Studies No. 31, p. 13-26. Retrieved on $27^{\text {th }}$ March, 2015, from http://catalog.lib.kyushu-u. ac.jp/handle/2324/21899/p013.pdf

Kang, N \& Zhang, Y. (2008). On the Translation of Public Sign Expressions. in Asian Social Science Journal Vol. 4, No. 8, p. 124-128. Retrieved on $17^{\text {th }}$ January, 2012, from ccsenet.org/journal/index.php/ass/article/ download/1207/1170

Machali, R. (2000). Pedoman bagi Penerjemah. Jakarta: PT Grasindo.

Molina, L \& Albir, A.H. (2002). Translation Techniques Revisited: A Dynamic and Functionalist Approach. Retrieved on $19^{\text {th }}$ January 2008 , from http://id.erudit.org/ierudit/008033ar.

Nababan, Nuraeni \& Sumardiono. (2010). Pengembangan Model Penilaian Kualitas Terjemahan. Laporan Penelitian Hibah Kompetensi. Surakarta: Universitas Sebelas Maret.

Pengembangan Model Penilaian Kualitas Terjemahan. Dalam jurnal Kajian Linguistik dan Sastra, Vol. 24, No.1, Juni 2012:39-57.

Nida, E. A. (1964). Towards a Science of Translating. Leiden: E. J. Brill. 